\title{
Modern neuraxial labor analgesia: options for initiation, maintenance and drug selection
}

\author{
MARC VAN DE VELDE \\ Director Obstetric Anesthesia and Extra \\ Muros Anesthesia \\ Department of Anesthesiology, \\ University Hospitals Gasthuisberg \\ Herestraat 49, B-3000 Leuven, Belgium. \\ E-mail: marc.vandevelde@uz.kuleuven.ac.be
}

Most authors would agree that central neuraxial analgesia is the best form to manage labor pain. When neuraxial analgesia is administered to the parturient in labor, different management choices must be made by the anesthetist: how will we initiate analgesia, how will analgesia be maintained, which local anesthetic will we use for neuraxial analgesia and which adjuvant drugs will we combine? The present manuscript tries to review the literature to answer these questions.

\section{INITIATION OF NEURAXIAL ANALGESIA}

1most two decades have passed since French and American trials A evaluated the use of spinal opioids during labor and since European randomized trials compared conventional epidural analgesia with combined spinal epidural (CSE) analgesia (1-3). CSE analgesia has gained worldwide acceptance and is becoming increasingly popular as the method of choice for labor pain relief (4-9). Obstetric anesthetists are divided when questioned on the place of CSE in labor analgesia. Whilst some authors feel it should be the technique of choice, others reserve CSE for certain indications (10-15). Recently, Simmons et al. published a Cochrane review concluding that CSE offers little benefit as compared to conventional epidural analgesia (16). However, the authors of this meta-analysis did acknowledge that CSE produced faster analgesia, resulted in less need for rescue analgesia and was associated with less urinary retention. Apart from a slight increase in the incidence of pruritus, these beneficial effects were not associated with more complications. The three demonstrated benefits of CSE are sufficient to promotes it's use if the side-effect profile remains unaltered. Furthermore it must be stressed that this Cochrane review can be criticized. Firstly, a number of well performed studies were excluded from analysis because of uncertain reasons. Inclusion of these well performed studies into the analysis might have affected the overall conclusions. Secondly, a number of outcomes were not considered in the analysis such as one-sided analgesia, epidural catheter reliability, anesthetist intervention rate, local anesthetic consumption and the occurrence of fetal heart abnormalities. Finally, very different types of CSE were used in the various studies. They were all considered to be a generic procedure and analyzed combined.

Arguably the most obvious advantage of the CSE technique is the rapid and spectacular onset of effective analgesia with minute concentrations of local anesthetics with or without adjuvant drugs (16). Consistently, effective labor analgesia is accomplished within 4-6 minutes 
following intrathecal injection (1, 2, 17-29). Following conventional epidural analgesia, initial analgesia is usually achieved between 15 and 25 minutes. Some detractors argue that conventional epidural analgesia provides equally fast analgesia (23). It is important to note, however, that although the onset time of epidural analgesia might be reasonable, the reported values are means. With epidural analgesia a wide inter-patient variability exists depending on parity, stage of labor and other relevant obstetric and non-obstetrical factors. Especially during late labor, analgesia following an epidural injection is often delayed and only successful if large doses are administered. With CSE, onset time is short in all patients.

Several trials demonstrated lower VAS scores for labor pain with CSE as compared to epidural analgesia (18, 30-32). However, other comparative trials could not demonstrate a difference in VAS scores for pain $(23,33,34)$. No trials report higher VAS scores with CSE. Most likely especially during the first 30 to 60 minutes VAS scores are lower when patients are treated with CSE.

Most anesthesiologists would agree that CSE provides better quality analgesia throughout the course of labor (35). Vernis and co-workers demonstrated that less patients reported unilateral analgesia with CSE (29). Interestingly, Hess et al. investigated the factors associated with breakthrough pain during neuraxial labor analgesia and found that patients treated with conventional epidural analgesia were three times as likely to experience recurrent breakthrough pain as compared to CSE treated women (36). In contrast however, Goodman et al. in a prospective study noted that additional top-ups to treat breakthrough pain were requested by similar numbers of patients irrespective of the analgesic strategy used (37).

The presence of a dural puncture may facilitate the passage of epidurally administered drugs during maintenance of analgesia to the cerebrospinal fluid. At least in animals such an effect has been reported (38). In patients, Leighton et al. also reported that epidural bupivacaine blocked more dermatomes when administered following an initial dural puncture as compared to epidural bupivacaine administered without prior dural puncture (39). Leighton et al. used a 24 and 27G spinal needle. Cappiello and co-workers performed a randomized, double-blind study in which the dura was perforated with a $25 \mathrm{G}$ Whitacre needle without administration of spinal drugs (40). The control group had no dural puncture. Patients treated with a dural puncture had better sacral spread, shorter onset of analgesia and better quality pain relief. Thomas et al. performed a similar study using a $27 \mathrm{G}$ Whitacre needle and could not find a difference between patients treated with or without a dural puncture (41). So spinal needle size may be important. Many studies report higher patient satisfaction with CSE (18, $19,27,42)$, while no studies report on the opposite.

Despite similar or improved quality of analgesia, local anesthetic requirements are significantly reduced with $\operatorname{CSE}(18,19,27,29)$. Discussion remains whether this is the result of the omission of the initial epidural bolus or that also during labor a dose sparing effect persists. The presence of the dural whole and the facilitated passage of epidurally administered local anesthetics could offer part of the explanation.

Following initial spinal analgesia, bilateral analgesia and sensory changes occur, making testing of the epidural catheter difficult. The epidural catheter cannot prove itself and many may question the reliability of the catheter to achieve bilateral analgesia once the spinal dose is worn off. However various investigators noted that the reliability of epidural catheters following CSE was significantly increased as compared to stand alone epidural catheters $(40,41,43-48)$ (Table 1). There was less need for epidural catheter replacement and there was less unilateral analgesia requiring catheter manipulation. Lee et al. reported less catheter failure when topping up for Cesarean section when the catheter was placed as part of a CSE technique of labor analgesia (44).

When using a CSE technique, a perfect midline approach is required to identify the subarachnoid space and consequently more epidural catheters reliably are positioned into the epidural space (48). Thomas et al. interestingly noted that when no cerebrospinal fluid was obtained following attempted CSE, subsequently much more epidural catheters required replacement as compared to those catheters placed when cerebrospinal fluid was noted (41).

The CSE technique may have more complications. What does the literature tells us? Pruritus is the most common side effect of intrathecal opioids, occurring in almost all patients, if directly questioned $(18,27,29,45)$. In the most recent Cochrane review, pruritus was more frequent following CSE and was reported to be the online complication occurring more frequent as compared with conventional epidural analgesia (16). It usually develops shortly after analgesia. It is mild and hardly ever requires antipruritic therapy. Since patients hardly ever require therapy and seldom report pruritus as a reason for dissatisfaction, pruritus is no reason to refrain from using CSE and intrathecal opioids.

\section{TABLE 1}

Reliability of epidural catheters: \% of failed epidural catheters not producing adequate analgesia and that were resited.

\begin{tabular}{|lcc|}
\hline & CSE & Epidural \\
\hline Norris 2000 (46) & $0.2 \%$ & $1.3 \%$ \\
COMET 2001 (43) & $4.0 \%$ & $6.8 \%$ \\
Van de Velde 2001 (48) & $1.49 \%$ & $3.18 \%$ \\
Thomas 2005 (41) & $9.3 \%$ & $8.0 \%$ \\
Cappiello 2008 (40) & $3 \%$ & $13 \%$ \\
Lee 2009 (44) & $1 \%$ & $6 \%$ \\
Miro 2008 (45) & $3.4 \%$ & $6.2 \%$ \\
\hline
\end{tabular}

* Thomas et al. reported more catheter replacement when the spinal component failed $(22.2 \%)$. 
Nausea and vomiting are very rare complications during CSE and conventional epidural analgesia. No differences in the incidence of nausea have between reported when comparing the two techniques, except in the retrospective trial by Miro et al. who reported more nausea and vomiting in patients treated with epidural analgesia (45). We must remember that nausea is a part of the birth process especially during induced labour.

Both CSE and conventional epidural analgesia have been associated with usually mild hypotension, which is easily treated (49). Hypotension following the spinal injection is transient and occurs within the first 30 minutes following initiation of analgesia $(29,50,51)$. In clinical, routine practice it is important to avoid the supine position. We always keep our patients in the completely left lateral decubitus position to avoid any effect of aortacaval compression.

Although opioids do not produce sympatholysis, hypotension is observed with pure intrathecal opioid analgesia (52-55). When local anaesthetics are combined, hypotension seems to be more pronounced, but clinically usually easily treated (54). Intrathecal clonidine, however, is often associated with severe hypotension and this author can not recommend it's routine use based on his personal experience with this drug. Hypotension can be severe and is often protracted requiring prolonged supportive vasopressor therapy $(56,57)$.

Respiratory depression is a recognized complication of intrathecal opioids during labor, probably as a result of rostral spread. Several case reports have demonstrated that lipid soluble opioids may induce this potentially life threatening complication $(21,58-65)$. In some, but not all, cases respiratory arrest occurred in relatively short stature women who had received parenteral or epidural opioids prior to the spinal injection. Fortunately, respiratory depression occurred typically within the first 30 minutes and was easily treated and reversed using naloxone. In one patient chest compressions and resuscitation was required (65). Ferrouz et al. performed a retrospective chart analysis and reported 1 respiratory arrest in over $5000 \mathrm{CSE}$ performed with $10 \mu \mathrm{g}$ spinal sufentanil (59). As this complication is rare, most authors advocate vigilance and advise to use lower doses of intrathecal opioids then those initially used on empirical grounds (66). Other complications related to excessive rostral spread of opioids and local anaesthetics have been described and include: aphonia, aphagia, dysphagia, altered levels of consciousness, high sensory block, transient swallowin difficulties, etc... (67-72). Also sudden hypoglycemia has been described $(73,74)$.

Some authorities claim that the risk of central nervous system infections is increased secondary to the breach of the dura (75). However, Camann and Birnbach both agree that at the moment there is no scientific evidence indicating that CSE analgesia is associated with more infectious problems than epidural analgesia $(76,77)$. Indeed several case reports of meningitis or epidural abscess have been reported following CSE anesthesia in obstetric patients $(29,78-82)$, but also with simple spinal anesthesia and conventional epidural techniques central nervous system infections have been reported (83-86). Despite these occasional case reports, CNS infections remain extremely rare irrespective of the neuraxial technique used. Six publications evaluate the risk of infections following neuraxial anesthesia in obstetric patients (66, 87-91). In over 900.000 patients only 2 cases of epidural abscess and 3 cases of meningitis were reported. Most authors, however, agree that strict aseptic techniques are of vital importance to prevent serious infections.

Several case reports in pregnant women of damage to the conus medullaris have been reported when using CSE (92). Especially with CSE it is imperative to perform the block as low as possible since the conus medullaris might extend below the L2 vertebral body. Up to $5 \%$ of parturients can have a conus which extends lower than the L2 vertebral body (93). To avoid conus damage, careful attention to the correct interspace is required. It has been clearly demonstrated, using radiography and ultrasound, that most anesthetists, using anatomical landmarks, are 1 to 4 interspaces away from where they think to be $(93,94)$. Identification of the correct interspace is therefore of prime importance. Ultrasound may be useful, especially in obese patients, to indetify or confirm the correct interspace (93).

Since CSE includes a dural puncture, there is a theoretical risk of postdural puncture headache (PDPH). This is a devastating complication in an otherwise healthy mother, keen on taking care for her newborn child. However the use of small-gauge atraumatic spinal needles (26-29 G) has dramatically decreased the problem. From the available literature it seems that PDPH occurs in no more than $1 \%$ of patients. Furthermore the incidence is not increased as compared to conventional epidural analgesia $(18,29,35,42,43,45,47,49,53,76,95,96)$. Norris et al. reported that unintended dural puncture with the epidural needle occurs much more frequent when using conventional epidural analgesia as compared to CSE (49) Rarely the spinal needle itself is responsible for PDPH. Usually a dural tap with either the Tuohy needle or the epidural catheter causes postural headache. It is also worthwhile to mention several reports advising to insert the epidural catheter in the subarachnoid space following an accidental dural tap. The incidence of PDPH and bloodpatching seems reduced when the epidural catheter is threaded intrathecally (96-100). Of interest is that air should be replaced by saline in the loss of resistance technique, as air might cause more PDPH, increase it's severity and induce other problems with your epidural block such as recurrent breakthrough pain (101, 102).

For many years, strategies to reduce the incidence and severity of motor block, associated with epidural analgesia, have been designed. Lower concentrations of local anesthetic solutions, the addition of opioids and other adjuvant drugs, the introduction of patient controlled epidural analgesia and the use of newer local anesthetic 
agents have been instrumental in reducing problematic motor block. Low dose epidurals are successfully used to allow laboring women to maintain mobility whilst being completely pain free $(19,95)$. With CSE it is easier to provide effective analgesia with no or very minute doses of local anesthetics. As already described, CSE decreased total local anesthetic consumption $(18,19,27)$ and decreased the occurrence of motor block compared to standard epidural techniques $(18,19,27,95)$.

Some authors have questioned the safety of walking during labor and neuraxial analgesia. However, several authors demonstrated that with CSE motor function and balance remained intact, whilst low dose epidurals induced clinically detectable dorsal column deficits (82, $103,104)$. Ambulation is become common practice and can be advised, provided adequate precautions, written protocols and testing of motor function following initiation of analgesia is performed. Motor function testing is straightforward and includes the ability to perform a deep knee bend unassisted and to perform a straight leg lift for 30 seconds with the eyes closed. Caution is required when using epidural test doses following insertion of an epidural catheter, since test doses can significantly impair motor strength (105). Controversy also exists on the effects of spinally administered epinephrine $(28,106)$ on motor block. Whilst minute doses do not impair motor function, larger doses have a significant impact $(64,106)$.

Epidural analgesia has been implicated in prolonged labors, an increased instrumental delivery rate and an increased Cesarean section rate. Extensive research has now led to unanimous consensus that epidural analgesia does not produce more instrumental vaginal and operative deliveries. However, epidural analgesia prolongs the duration of the first stage of labor and increases the need for exogenous oxytocin. Tsen et al. demonstrated in a prospective, randomized trial that CSE is associated with an increased cervical dilation rate (107). Patients randomized to CSE analgesia experienced a doubling of the mean cervical dilation rate and a reduced duration of the first stage of labor as compared to epidural analgesia (107). Disappointingly, several randomized trials comparing CSE with conventional epidural analgesia could not demonstrate a difference in labor duration $(19,26$, $27,47)$. CSE as compared with low dose epidural strategies was not associated with an increased spontaneous vaginal delivery rate in most trials $(7,18,19,26,33,42$, 47). Only one trial reported less instrumental vaginal deliveries with CSE as compared to epidural analgesia (95).

Abnormal fetal heart rate recordings and fetal bradycardia are worrisome side effects that may follow any type of effective labor analgesia. Some authors reported that this complication could be more common following intrathecal opioids than following conventional epidural analgesia (108-111). Clarke et al. were the first to describe in detail the association between intrathecal opioids, uterine hyperactivity and fetal bradycardia in the absence of maternal hypotension (108). Since then sev- eral non-randomized trials have evaluated the incidence of fetal heart rate changes following either intrathecal opioids and conventional epidural analgesia $(48,112$ 114). Nielsen $e t$ al. and Eberle et al. did not observe an increased incidence of fetal heart rate abnormalities, whilst all other non-randomised reports noted at least a doubling of the incidence of worrisome fetal heart rate changes.

Mardirossof et al. performed a meta analysis of several prospective trials comparing intrathecal opioid analgesia with non-intrathecal opioid analgesia with respect to fetal bradycardia (115). These authors concluded that intrathecal opioids were associated with significantly more fetal heart rate abnormalities. Vercauteren suggested that the incidence of fetal bradycardia depended on the dose of the intrathecal opioid (116). Van de Velde et al. concluded that high doses of intrathecal opioids increased the incidence of fetal heart rate abnormalities despite a reduced incidence of hypotension (27). Similar results were published by Nicolet et al. (117). These authors also indicated that older age and higher VAS scores prior to analgesia were risk factors associated with fetal heart rate abnormalities after CSE. Gaiser suggested that the risk of abnormalities in the fetal heart rate is increased when the fetal head is not engaged or when decelerations are already present prior to initiation of analgesia (118).

The presumed mechanism of opioid induced non-reassuring fetal heart rate tracings is uterine hyperactivity caused by rapid analgesia and as a result a rapid decrease in maternal circulating cathecholamines. Abrao et al. recently measured uterine tone using an intrauterine epressure catheter following either CSE or conventional epidural analgesia (119). Fetal heart rate changes and uterine hypertonus occurred more frequently following CSE. Analgesia was initiated rather late in labor and unfortunately these authors only measured intrauterine tone and fetal heart rate for 15 minutes after initiation of analgesia. So changes associated with epidural analgesia might have been missed. They also demonstrated that the faster analgesia occurred and the more pronounced it was, the higher the probability of abnormal cardiotocographic readings. Of course this effect is strengthened by the simultaneous occurrence of maternal hypotension in certain patients.

It is important to note that neonatal and obstetric outcome is not affected by the use of intrathecal opioids. Carvalho et al. failed to demonstrate any changes in fetal oxygen saturation following CSE analgesia (119). In none of the reports emergent $\mathrm{C}$-sections had to be performed as a result of sufentanil induced non-reassuring fetal heart rate tracings $(27,28,112,113,114,115,118$, 120, 121). Also neonatal outcome, as assessed by Apgar scores, umbilical artery $\mathrm{pH}$ and admittance to the neonatal intensive care, was unaffected by the technique used. Albright and Forster performed an institutional retrospective survey involving 2500 patient records and observed no increase in emergency Cesarean delivery associated to the use of intrathecal opioids (122). Only Gambling et al. contradicted this and reported an in- 
creased C-section rate due to more non-reassuring fetal heart rate abnormalities (123). However also in their study neonatal outcome was good and not different from the epidural group.

Since epidural catheters can inadvertently be misplaced in either the cerebrospinal fluid or in an epidural vein, anesthetists have been using test doses to verify the correct position of the catheter. Unfortunately, test doses are neither sensitive nor specific $(124,125)$. Furthermore epinephrine containing test doses can induce motor impairment and thus complicate ambulation during labor (105). Some authors also suggested that an epinephrine containing test dose has potential adverse effects on uteroplacental perfusion (126). As a result several authors suggested to abandon routine testing of the epidural catheter, since adequate analgesia confirms the correct position of the catheter without prior testing (127).

With CSE, analgesia occurs rapidly and testing the functionality of the epidural catheter is not possible until the initial spinal dose wears off. Many authors consider the fact that the reliability of the epidural catheter is uncertain during this period as a major disadvantage. Their concern is related to the possibility that the catheter may be dysfunctional when an emergency cesarean section is required. Especially in high risk pregnancies this is considered a major drawback. However, it is important to note that even with a well tested epidural catheter, we can never be absolutely sure that several hours later the catheter remains correctly positioned. Even with conventional epidural catheters fractioned dosing or a de novo test dose are required the moment the catheter is used for the injection of high doses of local anesthetics.

A second concern involves the fact that some authors do not want to initiate epidural analgesia immediately after the spinal dose. Only when the epidural catheter is formally tested once the spinal dose has worn off, the catheter is used throughout labor. As a result most patients will experience breakthrough pain. However, several authors initiate an epidural infusion immediately following the initial spinal dose. With low volume, low dose techniques, the risk of total spinal anesthesia or toxic side effects is minimal. These doses cannot produce systemic toxicity or total spinal anesthesia even when direct intravascular or intrathecal injection occurs. However if a continuous epidural infusion or patient controlled epidural analgesia does not produce adequate analgesia, one must consider an intravascular position of the catheter.

Currently, a local anesthetic (bupivacaine, ropivacaine or levobupivacaine)/opioid (fentanyl/sufentanil) mixture is used to initiate spinal anesthesia. Van de Velde et al. were the first to construct the full dose response relationship of spinal ropivacaine, levobupivacaine and bupivacaine combined with opioids for labor analgesia (128). These investigators noted that bupivacaine was significantly more potent then both other local anesthetics and that ropivacaine and levobupivacaine were of similar potency (128). They also noted that in active labor much more local anesthetic was required then previously described on empirical grounds to produced affective analgesia in all parturients.

Several authors have suggested to prolong initial intrathecal analgesia by the addition of various other drugs such as clonidine, epinephrine and neostigmine. Although these drugs were succesfull in prolonging analgesia, they also produced significantly more side-effects.

\section{MAINTENANCE OF ANALGESIA}

Maintenance of analgesia can be achieved using either intermittent top-ups (ITU), continuous epidural infusions (CEI) or patient controlled epidural analgesia (PCEA) with or without a background infusion. In California, only $25 \%$ of obstetric anaesthesia units used PCEA in 2005 (129). In the United Kingdom only 5\% of units used PCEA in 1999 (130). However in Belgium in 2005, the majority of hospitals used PCEA (131).

The pros and cons of ITU, CEI and PCEA by comparing them to each other will be reviewed. We will evaluate quality of analgesia and incidence of unwanted side-effects of analgesia according to the mode of maintaining analgesia.

\section{Intermittent top-ups versus continuous infusion}

The administration of intermittent top-ups is historically the first modality with which epidural analgesia was maintained. Anaesthetists or midwifes administer a bolus of local anaesthetic solution either on patient request or after a fixed interval. Several potential problems however may arise. Administration of large doses of local anaesthetic in bolus can lead to systemic toxicity. Furthermore bolus administration may elicit maternal hypotension and fetal heart rate abnormalities. Additionally, ITU can lead to periods of inadequate pain control. As a result investigators tried to improve epidural analgesia by developing CEI.

Lamont et al. demonstrated that ITU are indeed associated with more additional top-ups, that hypotensive episodes are more frequent, that fetal heart rate changes occur with a higher frequency, that more babies require admission to the neonatal care unit and that quality of analgesia is less then with CEI (132). Also D'Athis et al. showed that CEI is associated with better analgesia and less local anaesthetic consumption (133). However many studies reported no differences in terms of analgesic quality between ITU and CEI (133-135), and some reported that ITU was associated with better analgesia (136-137). Most studies also showed that local anaesthetic consumption is reduced with ITU $(133,134,136,137)$. Despite less anaesthetic consumption, obstetric outcome is usually similar between the two modalities (135-140), except for more spontaneous deliveries with ITU in the study by Smedstad et al. (134). So basically, CEI and ITU are quite similar in terms of quality of analgesia and incidence of side-effects with a tendency towards better performance for the ITU technique. 


\section{Patient controlled epidural analgesia (PCEA) versus intermittent top-ups}

Several studies compared PCEA with ITU techniques of maintaining epidural analgesia during labour (135, 137, 140-144). Quality of pain relief was similar between the two modalities, except in the study by Paech et al. (143): ITU resulted in higher maximal pain scores. Also in the study by Halonen et al. PCEA produced better analgesia (141). Gambling et al. reported increased satisfaction scores with PCEA as compared to ITU, but other authors could not confirm these results (144). In terms of local anaesthetic consumption reported results are conflicting: most studies show no difference, while some report an increased consumption with PCEA and others report a decreased consumption with PCEA (137, 141-143). Two studies demonstrate a negative effect on obstetric outcome with PCEA $(141,143)$. Paech et al. observed a prolonged second stage of labour, while Halonen et al. noted more Caesarean sections as well as a longer second stage $(141,143)$.

\section{Patient controlled epidural analgesia (PCEA) versus continuous epidural infusions (CEI)}

Numerous studies have evaluated PCEA since it's introduction into obstetric analgesia in 1988 by Gambling et al. (145). PCEA produced similar levels of pain relief in most studies in terms of recorded Visual Analogue Scores for pain $(135,137,140,145-155)$. However, quality of pain relief is more than recorded VAS scores. One important parameter is the incidence of breakthrough pain requiring medical staff (anaesthetist) intervention. Although theoretically CEI may require fewer anaesthetist interventions, most studies indicate that just the opposite is true. PCEA is associated with less medical staff interventions. This was clearly demonstrated by an excellent meta-analysis by van der Vyver et al. comparing PCEA with CEI (156). Some studies also showed that patient satisfaction was increased with the PCEA modality (147). Patient satisfaction is increased because of increased patient responsibility, patient control of labour experience, patient titration to the desired level of pain and a considerable placebo effect by pressing the PCEA button.

PCEA is also associated with significantly less local anaesthetic consumption (156). Reductions vary from study to study between $20 \%$ less to $55 \%$ less local anaesthetic consumption. As a result significantly less motor block is observed with PCEA (156). It remains unclear whether this results in a better obstetric outcome. Most studies can not identify a difference between both modalities. However, some indicate less outlet forceps deliveries may be required when using PCEA $(148,253,154)$. The meta-analysis by van der Vyver et al. could not confirm this however (156).

The use of background infusions combined with a PCEA modality is controversial. Some authors indicate that a background infusion confers no benefit while oth- ers suggest better pain scores with a background infusion (157-159). However the difference may be that a background infusion seems particularly useful when analgesia is initiated with CSE. The background infusion ensures epidural priming when the patient requests the first epidural bolus. When the epidural space is primed more rapid and more effective analgesia is most likely obtained $(158,159,160)$.

In recent years several authors have evaluated the use of PCEA combined with automated intermittent boluses. Both Wong et al. and Sia et al. compared automated boluses with continuous background infusion both combined with PCEA $(161,162)$. In both studies automated boluses performed better resulting in less local anaesthetic consumption, less clinician intervention and better quality of pain relief. Now, several studies are emerging looking at computer integrated PCEA. Computer integrated PCEA is a conventional PCEA system but with an automated feedback loop: the rate of a continuous background infusion is adapted according to the administered PCEA boluses during the previous hour (163). Computer integrated PCEA resulted in less breakthrough pain and higher parturient satisfaction.

\section{CONCLUSION}

Based on the literature, PCEA and ITU seem to be superior options compared to CEI for maintenance of labour analgesia. Both modalities result in less local anaesthetic consumption, less motor block and increased patient satisfaction as compared to CEI. PCEA may be slightly more expensive then ITU, but results in far less medical staff workload. Depending on local legislation, ITU may not be an option. PCEA with a background infusion, especially when CSE is used, may be a good option. However te background infusion rate should be small (no more than $25 \%$ of total hourly consumption). New PCEA modalities are being developed.

\section{Choice of local anesthetic}

Bupivacaine is worldwide probably the most commonly used drug for obstetric regional anaesthesia and analgesia. Reports of bupivacaine cardiotoxicity after unintentional intravascular injection mainly in obstetric patients have led to the development of ropivacaine and levobupivacaine (164). These drugs appear to be safer alternatives as compared to bupivacaine. These drugs also have a greater separation between sensory and motor blockade, an especially advantageous feature during labour analgesia. Since these drugs were marketed, the pharmaceutical industry is pushing anaesthetists to change their practice in favour of these new local anaesthetic agents. Is this the correct strategy to follow? What is the place of racemic bupivacaine in modern obstetric analgesia?

\section{Risk of systemic toxicity}

All local anaesthetics can produce systemic toxicity by direct and indirect mechanisms that derive from their 
mode of local anaesthetic actions, i.e. inhibition of voltage-gated ion channels $(165,166)$. Furthermore local anaesthetics also interfere with mitochondrial respiration by impeding oxidative phosphorylation, thus depleting the cell's energy reserve. Ropivacaine and levobupivacaine both have lower systemic toxicity then bupivacaine (165-167). Ropivacaine seems to be the least toxic, levobupivacaine has intermediate toxicity and bupivacaine is most toxic. Evidence comes from numerous in vitro cellular studies, ex vivo whole organ studies, whole body studies in animals, whole body studies in human volunteers and case reports. Reduced systemic toxicity has also been demonstrated in pregnant animals (168).

Caution remains essential in using large volumes or doses of local anaesthetic. These new local anaesthetics should not be regarded as "safe" but as "safer" alternatives to bupivacaine. It remains essential that clinicians use the customary precautions to minimize the risk of systemic toxicity e.g. standard monitoring, aspiration of the catheter prior to injection of local anaesthetics, use of a test dose, fractionation of the injected dose and use of the lowest local anaesthetic concentration feasible.

\section{Excellent labour analgesia with minimal side-effects}

One of the factors implicated in the association between epidural analgesia and increased rates of operative delivery is motor block from epidural local anaesthetic. Motor block can be minimized by reducing the concentration of local anaesthetic, by decreasing the total dose used or by choosing a local anaesthetic with a high differential sensory:motor block ratio.

Several trials have evaluated conventional labour analgesia using rather high concentrations of different local anaesthetics $(\geq 0.2 \%)$. A meta-analysis of six trials compared $0.25 \%$ of ropivacaine with $0.25 \%$ bupivacaine. A

\section{TABLE 1}

Number of patients with motor block in bupivacaine or ropivacaine treated patients using similar and low $(\leq 0.125 \%)$ concentrations of local anaesthetic. ${ }^{*} \mathrm{p}<0.05$ versus bupivacaine.

\begin{tabular}{|lccc|}
\hline & $\begin{array}{c}\text { Bupi- } \\
\text { vacaine }\end{array}$ & $\begin{array}{c}\text { Ropi- } \\
\text { vacaine }\end{array}$ & $\begin{array}{c}\text { Number of } \\
\text { patients }\end{array}$ \\
\hline Campbell et al. (173) & 5 & $0^{*}$ & 40 \\
Meister et al. (174) & 18 & $8^{*}$ & 50 \\
Gautier et al. (175) & 15 & $3^{*}$ & 90 \\
Lee et al. (176) & 21 & 10 & 346 \\
Owen et al. (178) & 12 & 8 & 50 \\
Gogarten et al. (179) & 11 & 4 & 109 \\
Chua et al. (180) & 5 & 3 & 32 \\
Fischer et al. (181) & 19 & 10 & 189 \\
Atienzar et al. (177) & 18 & 13 & 65 \\
TOTAL & 124 & 59 & 971 \\
\hline
\end{tabular}

total of 391 patients were analysed. The authors concluded that ropivacaine produced less motor block, resulted in a higher spontaneous vaginal delivery rate and had less effects on the neurological adaptive capacity scores (NACS) of the neonates (169). Asik et al. produced similar results comparing $0.2 \%$ ropivacaine and bupivacaine solutions combined with fentanyl for epidural labour analgesia: less motor block and more spontaneous vaginal deliveries were noted (170).

However, modern labour analgesia uses far lower concentrations of local anaesthetics. The advantages in terms of motor block and labour outcome of lower epidural local anaesthetic concentrations were well demonstrated by the COMET trial (171). Halpern and Walsh performed a meta-analysis of 23 randomised trials that compared ropivacaine and bupivacaine during labour analgesia (172). Onset, duration and quality of analgesia were perfectly comparable between the two local anaesthetics. No differences in mode of delivery or other outcome parameters were identified, except for a more frequent incidence of motor block with bupivacaine. The results related to motor block were not combined statistically because of the large amount of heterogeneity among studies resulting from the large differences in drug doses and concentrations used among studies. If one outcome parameter, however, is not evaluated statistically because differences in methodology among studies, why then compare other outcome parameters despite these methodological differences among studies?

Several individual studies using low concentrations of local anaesthetic $(\leq 0.125 \%)$ however did demonstrate differences in motor block with ropivacaine producing less motor block then bupivacaine (173-181). Gautier et al. clearly demonstrated that, especially if the cumulative epidural dose of local anaesthetic increased, the risk of motor block was increased with bupivacaine (175). This difference persisted if lower concentrations of epidural bupivacaine were used to provide analgesia. Table 1 gives an overview of motor block reported in several studies that compared low and similar concentrations of ropivacaine and bupivacaine during labour analgesia. Combined, it becomes clear that motor block occurs much less with ropivacaine. Atienzar demonstrated that both ropivacaine and levobupivacaine produced less motor block (177).

This has been recently confirmed using the MLAC methodology. Lacassie et al. determined the motor block MLAC concentration of ropivacaine and bupivacaine using a model of up-and-down sequential allocation (182). These authors noted that ropivacaine was significantly less potent for motor block then bupivacaine, at $66 \%$ that of bupivacaine.

Similar observations can be made for intrathecal ropivacaine and bupivacaine. Excellent analgesia is achieved with both agents using similar spinal doses but with less motor impairment in patients treated with ropivacaine. Table 2 gives an overview of the number of patients developing detectable motor block in various studies that compare intrathecal ropivacaine and bupivacaine (183-186). 
TABLE 2

Number of patients with motor block in bupivacaine or ropivacaine treated patients using similar doses of local anaesthetic administered intrathecally. ${ }^{\star} p<0.05$ versus bupivacaine.

\begin{tabular}{|lccc|}
\hline & $\begin{array}{c}\text { Bupi- } \\
\text { vacaine }\end{array}$ & $\begin{array}{c}\text { Ropi- } \\
\text { vacaine }\end{array}$ & $\begin{array}{c}\text { Number } \\
\text { of patients }\end{array}$ \\
\hline Levin et al. (183) & 0 & 0 & 48 \\
Hughes et al. (184) & 8 & $1^{*}$ & 40 \\
Lim et al. $(185)$ & 5 & $2^{*}$ & 40 \\
Camorcia et al. $(186)$ & 8 & 1 & 64 \\
TOTAL & 21 & 4 & 192 \\
\hline
\end{tabular}

For levobupivacaine less information is available. Lacassie et al. determined the motor block MLAC concentration of levobupivacaine and bupivacaine using a model of up-and-down sequential allocation (187). These authors noted that levobupivacaine was significantly less potent for motor block then bupivacaine, at $87 \%$ that of bupivacaine. Vercauteren et al. observed no clinical differences between spinal levobupivacaine and racemic bupivacaine except for less motor block with levobupivacaine (188).

\section{The clinical relevance of reduced potency}

So-called MLAC studies have repetitively demonstrated that ropivacaine and levobupivacaine are less potent during labour analgesia at the ED50 point of the dose-response curve then bupivacaine (189-191). Although MLAC studies have undoubtedly added to our understanding of local anaesthetics and their relative potency, there are several caveats when applying these results to the clinical situation of labour analgesia. First, MLAC studies only focus on one point of the dose response curve and provide no information on the slopes of the different dose response curves. Second, MLAC studies only focus on the concentration used and not on the total dose. However total dose, determines the intensity of sensory and motor block (192). Third, it is difficult to control for confounding factors such as stage of labour, parity, type of labour, etc..., factors that each individually impact on labour pain intensity. Fourth, MLAC studies determine relative potency for initiation of analgesia during labour, but do not provide information on relative potency during maintenance of analgesia (which might be influenced by factors such as local anaesthetic lipid solubility or effects of local anaesthetics on epidural vasculature). However, despite these criticism, most clinicians would agree that new local anaesthetics are indeed less potent then bupivacaine. Recently this has been confirmed by the first full dose response comparison of levobupivacaine, ropivacaine and bupivacaine, used for spinal labour analgesia (193). Other authors did propose a potency hierarchy: bupivacaine $>$ levobupivacaine $>$ ropivacaine (186).
Clinicians live, however, in the real world. Most of us are not interested in the ED50, but want all are patients to be without pain. This means we will overdose some patients, to achieve good analgesia for all. Various solutions to minimize overdosing have been successfully investigated such as patient controlled epidural analgesia (PCEA). It is this authors conviction that the new local anaesthetics contribute to minimizing the side-effects of systematic overdosing, which is unavoidable in many patients.

\section{CONCLUSION}

Ropivacaine and levobupivacaine are safer drugs, have less prolonged motor block following Caesarean section, demonstrate greater motor-sensory separation during labour analgesia, and result in better neonatal and labour outcome when higher concentrations of local anaesthetics are used throughout labour. Unfortunately until now no study could identify improved labor outcome with low concentrations of the new local anaesthetics. We feel that the slightly increased cost is justified by the advantages in terms of safety and motor block and we are convinced that every institution should replace bupivacaine by one of its newer alternatives, as have done we!

\section{Adjuvant drugs}

Different adjuvant drugs have been tested for use in neuraxial labour analgesia: opioids, clonidine, neostigmine, epinephrine, magnesium and adenosine.

\section{Opioids}

Opioids used for labour pain relief act through mechanisms in the dorsal horn. Activation of $\mu, \delta$ and $\kappa$ - receptors induces pre-synaptic inhibition of neurotransmitter release and produces post-synaptic neuronal membrane hyperpolarisation.

Pure epidural opioid analgesia is feasible in the early stages of labour. Capogna et al. determined the ED50 of epidural fentanyl and sufentanil using the MLAC methodology (194). To produce analgesia in $50 \%$ of patients a dose of $124 \mu \mathrm{g}$ fentanyl and $21 \mu \mathrm{g}$ sufentanil was required, establishing a potency ratio of 5.9 between sufentanil and fentanyl.

However, usually opioids are combined with local anaesthetics. It has been repeatedly shown that opioids have a synergistic effect with various local anaesthetic agents. Opioids reduce the ED50 of different local anaesthetics (195). In clinical practice the addition of opioids reduces the onset of analgesia, prolongs the duration of initial epidural analgesia, reduces local anaesthetic consumption and decreases the incidence of patients with insufficient analgesia (196). The incidence of troublesome motor block is reduced and the rate of spontaneous vaginal delivery is increased (196). Unfortunately, more patients experience pruritus (196).

Plain intrathecal opioids are successful in producing labour analgesia. Palmer et al. established that fentanyl 
$25 \mu \mathrm{g}$ was the optimal intrathecal dose (197). Increasing the dose above $25 \mu \mathrm{g}$ did not improve the duration or quality of analgesia, but increased the incidence of side effects. For sufentanil an ED95 of $8.9 \mu \mathrm{g}$ was established (198). However, certainly in Europe, most anaesthesiologist prefer the intrathecal combination of local anaesthetics and opioids. Adding opioids to the spinal mixture, reduces the ED50 of the local anaesthetic agent and prolongs dose-dependently the duration of initial spinal analgesia (199).

Respiratory depression following intrathecal opioids has been described. This occurred usually in small patients receiving high doses of opioids following initial parenteral opioid analgesia. Respiratory depression occurred within 30 minutes from injection. Vigilance following the intrathecal injection of opioids is therefore required. During labour analgesia, intrathecal opioids have been associated with new onset foetal heart rate changes (27). Usually these changes were related to uterine hyperactivity and not maternal hypotension (27). Several authors postulated that an imbalance between maternal cathecholamines following rapid spinal analgesia produces uterine hypertonicity (27). It remains unclear why this only occurs following high dose intrathecal opioids and not following the combination of lower doses of opioids and local anaesthetics (27).

\section{Clonidine}

Clonidine, an $\alpha_{2}$-receptor agonist, acts through $\alpha_{2}$-receptors located in the dorsal horn to produce labour analgesia. Pre-synaptic stimulation of $\alpha_{2}$-receptors inhibits neurotransmitter release and post-synaptic stimulation prevents neuronal transmission through hyperpolarisation. Animal safety studies established that clonidine was not neurotoxic and did not affect spinal cord blood flow $(200,201)$.

A limited number of clinical trials have studied various doses $(30-150 \mu \mathrm{g})$ of epidural clonidine during labour. Based on the MLAC methodology, a minimum of $60 \mu \mathrm{g}$ clonidine is required to reduce the ED50 of ropivacaine for labour analgesia (202). Doses above $100 \mu \mathrm{g}$ induce maternal hypotension, bradycardia and sedation and in some trials also new onset foetal heart rate changes (203). Based on a dose response study of Brichant et al. and recent work by Landau $e t$ al. we conclude that the optimal epidural dose of clonidine is probably $75 \mu \mathrm{g}(204,205)$. Prolonged analgesia, reduced local anaesthetic consumption, less epidural top-ups for breakthrough pain without an increase in side effects were noted $(204,205)$.

Chiari et al. studied the use of pure spinal clonidine labour analgesia (206). This seems not feasible since doses producing adequate analgesia also induce unacceptable side effects such hypotension. Adding lower doses of clonidine (15-45 $\mu \mathrm{g}$ ) to spinal analgesics does improve the duration and quality of initial spinal analgesia $(207,208,209)$. However, especially when clonidine is combined with local anaesthetic agents, significant and prolonged hypotension is likely to occur $(208,209)$.

\section{Epinephrine}

Epinephrine also acts through $\alpha_{2}$-receptors. However vascular effects, especially with epidural administration might also be involved.

Epidurally administered epinephrine significantly reduces the MLAC concentration of bupivacaine in labouring patients and improves the quality of analgesia (210). Also for spinal use epinephrine, combined with local anaesthetics and opioids, has been evaluated in a wide range of doses from 2.25-100 $\mu \mathrm{g}$. Duration of intrathecal analgesia was consistently prolonged (211).

Unfortunately, epinephrine also induces an increased incidence of maternal motor deficit especially when administered epidurally or intrathecally $(212,213)$. Minute doses $(2.25 \mu \mathrm{g})$ of spinal epinephrine were not associated with more motor block. Epidural epinephrine might also prolong labour duration by $\beta$-agonist effects, especially when higher doses are infused in the epidural space (212-216). Furthermore adding epinephrine to pharmacist pre-prepared solutions complicates storage and significantly increases the price of handling and preparation. Thus, this author has abandoned the addition of epinephrine from the local anaesthetic solution used for spinal and epidural administration.

\section{Neostigmine}

Acetylcholine is an important neurotransmitter in the dorsal horn of the spinal cord for the descending inhibitory pathways. Neostigmine, a cholinesterase inhibitor, increases the concentration of acetylcholine in the synapses and thus stimulates analgesia by stimulating acetylcholine mediated mechanisms of analgesia. Naguib and Yaksh demonstrated that the analgesic effects of neostigmine and clonidine are synergistic (217). Following reassuring safety studies, in which no neurotoxic effects and no detrimental effects on spinal cord perfusion were identified, neostigmine has been evaluated for labour pain relief $(218,219)$.

Several trials evaluated the effects of epidural neostigmine $(220,221)$. Neostigmine seems to be promising as an adjuvant drug for labour analgesia.

Nelson et al. investigated the analgesic potential and side effect profile of 5, 10, $20 \mu \mathrm{g}$ intrathecal neostigmine alone (222). From this first phase, these investigators chose $10 \mu \mathrm{g}$ as the optimal dose to be added to intrathecal sufentanil and determined the ED50 of spinal sufentanil with and without neostigmine. Neostigmine successfully reduced the ED50 of spinal sufentanil. In a further step, they compared twice the ED50 of spinal sufentanil with neostigmine to twice the ED50 of plain spinal sufentanil. A synergistic effect on duration of analgesia of neostigmine was observed. D'Angelo et al. however reported no increase in analgesic duration with neostigmine as part of a multi-drug combination (local anaesthetic, opioid, clonidine and neostigmine) (223). Furthermore several authors reported a very high incidence of severe nausea and vomiting (224). 


\section{Other drugs: magnesium and adenosine}

Both adenosine and magnesium have been added to intrathecal opioids to relief labour pain $(224,225)$. No significant advantages of adding adenosine to the analgesic mixture were observed. Magnesium prolonged intrathecal fentanyl analgesia.

\section{Conclusion}

Local anaesthetic agents combined with opioids remain the cornerstone of effective spinal and epidural labour analgesia. Epidural clonidine is a valuable adjuvant drug, especially in difficult to control labour pain. An epidural dose of $75 \mu \mathrm{g}$ seems safe and effective. Spinal clonidine is effective but has been shown to induce difficult to control hypotension and should therefore be reserved for very specific situations. Routine us cannot be recommended by this author.

Epinephrine is a valuable drug but potential problems such as motor block, detrimental effects on the progress of labour and storage problems limit its usefulness. With neostigmine limited clinical experience is available. Spinal neostigmine produces unacceptable nausea and vomiting. Adenosine and magnesium have recently been studied during labour analgesia. Preliminary data are disappointing.

\section{CONCLUSIONS}

Based on experience and review of the literature, this author would answer the initial questions as follows:

How should we initiate labour analgesia?: Use a CSE because it provides reliable, fast analgesia with low doses of analgesic drugs and improves the effectiveness of your epidural catheter.

How should we maintain analgesia?: PCEA is the way forward.

Which local anaesthetic should we use? Probably, but still controversial, either ropivacaine or levobupivacaine because the possibility of less motor block.

Which adjuvant drugs?: Opioids, both epidurally and intrathecally, certainly whilst epidural clonidine and neostigmine are good candidates which need further study.

\section{REFERENCES}

1. CAMANN W R, MINTZER B H, DENNEY R A, DATTA $1993 \mathrm{~S}$ Intrathecal sufentanil for labor analgesia. Anesthesiology 78: 870-874

2. COLLIS R E, BAXANDALL M L, SRIKANTHARAJAH I D, EDGE G, KADIM M Y, MORGAN B M 1994 Combined spinal epidural analgesia: technique, management and outcome of 300 mothers. Int J Obstet Anesth 3: 75-81

3. ESCARMENT J, CLEMENT H J 1989 Use of epidural and intrathecal opiates in obstetrics. Ann Fr Anesth Reanim 8: 636-649

4. FUN W, LEW E, SIA A T 2008 Advances in neuraxial blocks for labor analgesia: new techniques, new systems. Minerva Anestesiol 74: $77-85$

5. PAECH M 2003 Newer techniques of labor analgesia. Anesth Clin North Am 21: 1-17
6. PETRE E, DYLST D, VANDERMEERSCH E, VAN DE VELDE M 2008 Obstetric anesthesia in Belgium: the First nationwide survey of current practice. Int J Obstet Anesth: S17, S21 (abstract).

7. RAWAL N 2005 Combined spinal epidural anaesthesia. Curr Opin Anaesthesiol 18: 518-521

8. RAWAL N, HOLMSTROM B, CROWHURST J A, VAN ZUNDERT A 2000 The combined spinal epidural technique. Anesth Clin North Am 18: 267-295

9. VAN HOUWE P, HEYTENS L, VERCRUYSSE P 2006 A survey of obstetric anaesthesia practice in Flanders. Acta Anaesthesiol Belg 57: $29-37$

10. COLLIS R E 2002 Combined spinal epidural analgesia is the preferred technique for labour pain relief. Acta Anaesth Belg 53: 283-288

11. KUCZKOWSKI K M 2007 Labor pain and its management with the combined spinal epidural analgesia: what does an obstetrician need to know? Arch Gynecol Obstet 275: 183-185

12. PLAAT F 1999 The dura is too vulnerable to be breached routinely in labour. Int J Obstet Anesth 8: 58-61

13. PRESTON R 2007 The role of combined spinal epidural analgesia for labour: is there still a question? Can J Anaesth 54: 9-14

14. RUSSEL R 1999 The dura is too vulnerable to be breached routinely in labour. Int J Obstet Anesth 8: 56-58

15. RUSSELL R 2002 Combined spinal epidural analgesia is the preferred technique for labour pain relief. Acta Anaesth Belg 53: 331-334

16. SIMMONS S W, CYNA A M, DENNIS A T, HUGHES D 2007 Combined spinal-epidural versus epidural analgesia in labour. Cochrane Database Systematic Reviews; issue 3, CD003401.

17. ABOULEISH A, ABOULEIS E, CAMANN W 1994 Combined spinal epidural analgesia in advanced labour. Can J Anaesth 41: 575-578

18. COLLIS R E, DAVIES D W L, AVELING W 1995 Randomised comparison of combined spinal epidural and standard epidural analgesia in labour. The Lancet 345: 1413-1416

19. COMET STUDY GROUP UK 2001 Effect of low dose mobile versus traditional epidural techniques on mode of delivery: a randomised controlled trial. The Lancet 358: 19-23

20. GAUTIER P E, DEBRY F, FANARD L, VAN STEENBERGE A, HODY J L 1997 Ambulatory combined spinal epidural analgesia for labor. Influence of epinephrine on bupivacaine-sufentanil combination. Reg Anesth 22: 143-149

21. HUGHES D, HILL D, FEE J P H 2001 Intrathecal ropivacaine or bupivacaine with fentanyl for labour. Brit J Anaesth 87: 733-737

22. JOOS S, SERVAIS R, VAN STEENBERGE A 1995 Sequential spinal epidural analgesia for pain relief in labour. Int J Obstet Anesth 4: 155-157

23. NICKELLS J S, VAUGHAN D J A, LILLYWHITE N K, LOUGHNAN B, HASAN M, ROBINSON P N 2000 Speed of onset of regional analgesia in labour: a comparison of the epidural and spinal routes. Anaesthesia 55: 17-20

24. PALMER C M, CORK R C, HAYS R, VAN MAREN G, ALVES D 1998 The dose response relation of intrathecal fentanyl for labor analgesia. Anesthesiology 88: 355-361

25. STACEY R G W,WATT S, KADIM M Y, MORGAN B M 1993 Single space combined spinal extradural technique for analgesia in labour. Br J Anaesth 71: 499-502

26. VAN DE VELDE M, MIGNOLET K, VANDERMEERSCH E, VAN ASSCHE A 1999 Prospective, randomized comparison of epidural and combined spinal epidural analgesia during labor. Acta Anaesth Belg 50: 129-136

27. VAN DE VELDE M, TEUNKENS A, HANSSENS M, VANDERMEERSCH E, VERHAEGHE J 2004 Intrathecal sufentanil and fetal heart rate abnormalities: a double blind, double placebo controlled trial comparing two forms of combined spinal epidural analgesia with epidural analgesia in labor. Anesth Analg 98: 1153-1159

28. VERCAUTEREN M, JACOBS J, JACQUEMYN Y, ADRIAENSEN H A 2001 Intrathecal labor analgesia with bupivacaine and sufentanil: the effect of adding $2.25 \mu \mathrm{g}$ epinephrine. Reg Anesth Pain Med 26: 473-477

29. VERNIS L, DUALE C, STORME B, MISSION J P, ROL B, SCHOEFFLER P 2004 Peripsinal analgesia followed by patient-controlled infusion with bupivacaine and sufentanil: combined spinal epidural vs epidural analgesia alone. Eur J Anaesthesiol 21: 186-192

30. GOODMAN S R, KIM-LO S H, CILIBERTO C F, RIDLEY D M, SMILEY R M 2002 Epinephrine is not a useful addition to intrathecal fentanyl or fentanyl-bupivacaine for labor analgesia. Reg Anesth Pain Med 27: 374-379 
31. KAYACAN N, ERTUGRUL F, CETE N, COSKUNFIRAT N, AKAR M, KARSLI B, ERMAN M 2006 Comparison of epidural and combined spinal epidural analgesia in the management of labour without pain. J Int Med Res 34: 596-602

32. STOCKS G M, HALLWORTH S P, FERNANDO R, ENGLAND A J, COLUMB M O, LYONS G 2001 Minimum local analgesic dose of intrathecal bupivacaine in labor and the effect of intrathecal fentanyl. Anesthesiology 94: 593-598

33. PRICE C, LAFRENIERE L, BROSNAN C, FINDLEY I 1998 Regional analgesia in early labour: combined spinal epidural versus epidural. Anaesthesia 53: 951-955

34. HEPNER D L, GAISER R R, CHEEK T G, GUTSCHE B B 2000 Comparison of combined spinal epidural and low dose epidural for labour analgesia. Can J Anaesth 47: 232-236

35. LANDAU R 2002 Combined spinal-epidural analgesia for labor: breakthrough or unjustified invasion? Sem Perinatol 26: 109-121

36. HESS P E, PRATT S D, LUCAS T P, MILLER C G, CORBETT T, ORIOL N, SARNA M C 2001 Predictors of breakthrough pain during labor epidural analgesia. Anesth Analg 93: 414-418

37. GOODMAN S R, SMILEY R M, NEGRON M A, FREEDMAN P A, LANDAU R 2009 A randomized trial of breakthrough pain during combined spinal-epidural versus epidural labor analgesia in parous women. Anesth Analg 108: 246-251

38. SWENSON J D, WISNIEWSKI M, MCJAMES S, ASHBURN M A, PACE N L 1996 The effect of prior dural puncture on cisternal cerebrospinal fluid morpine concentration in sheep after administration of lumbar epidural morphine. Anesth Analg 83: 523-525

39. LEIGHTON B L, ARKOOSH V A, HUFFNAGLE S, HUFFNAGLE H J, KINSELLA M, NORRIS M C 1996 The dermatomal spread of epidural bupivacaine with and without prior intrathecal sufentanil. Anesth Analg 83: 526-529

40. CAPPIELLO E, O'ROURKE N, SEGAL S, TSEN L C 2008 A randomized trial of dural puncture epidural technique compared with the standard epidural technique for labor analgesia. Anesth Analg 107: 1646-1651

41. THOMAS J A, PAN P H, HARRIS L C, OWEN M D, D'ANGELO R 2005 Dural puncture with a 27-Gauge Whitacre needle as part of a combined spinal-epidural technique does not improve labor epidural catheter function. Anesthesiology 103: 1046-1051

42. DRESNER M, BAMBER J, CALOW C, FREEMAN J, CHARL TON P 1999 Comparison of low-dose epidural with combined spinal epidural analgesia for labour. Br J Anaesth 83: 756-760

43. COMET study group 2002 Randomized controlled trial comparing traditional with two mobile epidural techniques. Anesthesiology 97: 1567-1575

44. LEE S, LEW E, LIM Y, SIA A T 2009 Failure of augmentation of labor epidural analgesia for intrapartum cesarean delivery: a retrospective review. Anesth Analg 108: 252-254

45. MIRO M, GUASCH E, GILSANZ F 2008 Comparison of epidural analgesia with combined spinal epidural analgesia for labor: a retrospective study of 6497 cases. Int J Obstet Anesth 17: 15-19

46. NORRIS M C 2000 Are combined spinal epidural catheters reliable? Int J Obstet Anesth 9: 3-6

47. NORRIS M C, FOGEL S T, CONWAY-LONG C 2001 Combined spinal epidural versus epidural analgesia. Anesthesiology 95: 913-920

48. VAN DE VELDE M, TEUNKENS A, HANSSENS M, VAN ASSCHE FA, VANDERMEERSCH E 2001 Post dural puncture headache following combined spinal epidural or epidural anaesthesia in obstetric patients. Anaesth Intensive Care 29: 595-599

49. NORRIS M C, GRIECO W M, BORKOWSKI M, LEIGHTON B L, ARKOOSH V A, HUFFNAGLE H J, HUFFNAGLE J 1994 Complications of labor analgesia: epidural versus combined spinal epidural techniques. Anesth Analg 79: 529-537

50. SHENNAN A, COOKE V, LLOYD-JONES F, MORGAN B, DE SWIET M 1995 Blood pressure changes during labour whilst ambulating with combined spinal epidural analgesia. BrJ Obstet Gynaecol 102: 192-197

51. MOSCHINI V, MARRA G, DABROWSKA D 2006 Complications of epidural and combined spinal epidural analgesia in labour. $\mathrm{Mi}$ nerva Anesthesiol 72: 47-58

52. CASCIO M, PYGON B, BERNETT C, RAMANATHAN S 1997 Labour analgesia with intrathecal fentanyl decreases maternal stress. Can J Anaesth 44: 605-609

53. MANDELL G J, JAMNBACK L, RAMANATHAN S 1996 Hemodynamic effects of subarachnoid fentanyl in laboring parturients. Reg Anesth 21: 103-111
54. NELSON K E, RAUCH T, TEREBUH V, D'ANGELO R 2002 A comparison of intrathecal fentanyl and sufentanil for labor analgesia. Anesthesiology 96: 1070-1073

55. RILEY E T, RATNER E F, COHEN S E 1997 Intrathecal sufentanil for labor analgesia: do sensory changes predict better analgesia and greater hypotension? Anesth Analg 84: 346-351

56. PEERAER A, TEUNKENS A, VANDERMEERSCH E, VAN DE VELDE M 2003 The effects of clonidine and epinephrine on the duration of spinal analgesia in labor and possible adverse maternal and fetal effects. Acta Anaesthesiologica Belgica 54(3): 253

57. CHIARI A, LORBER C, EISENACH JC, WILDLING E, KRENN C, ZAVRSKY A, KAINZ C, GERMANN P, KLIMSCHA W 1999 Analgesic and hemodynamic effects of intrathecal clonidine as the sole analgesic agent during first stage labor. Anesthesiology 91: 388-396

58. BAKER M N, SARNA M C 1995 Respiratory arrest after second dose of intrathecal sufentanil. Anesthesiology 83: 231-232

59. FEROUZ K, NORRIS M C, LEIGHTON B L 1997 Risk of respiratory arrest after intrathecal sufentanil. Anesth Analg 85: 1088-1090

60. GREENHALGH C A 1996 Respiratory arrest in a parturient following intrathecal injection of sufentanil and bupivacaine. Anaesthesia 51: 173-175

61. HAYS R L, PALMER C M 1994 Respiratory depression after intrathecal sufentanil during labor. Anesthesiology 81: 511-512

62. KATSIRIS S, WILLIAMS S, LEIGHTON B L, HALPERN S 1998 Respiratory arrest following intrathecal injection of sufentanil and bupivacaine in a parturient. Can J Anaesth 45: 880-883.

63. LU J K, MANULLANG T R, STAPLES M H, KERN S E, BAILEY P L 1997 Maternal respiratory arrests, severe hypotension, and fetal distress after administration of intrathecal sufentanil and bupivacaine after intravenous fentanyl. Anesthesiology 87: 170-172

64. PALMER C M 1991 Early respiratory depression following intrathecal fentanyl-morphine combination. Anesthesiology 74: 1173-1175

65. PAN P H, MOORE C H, ROSS V H 2004 Severe maternal bradycardia and asystole after combined spinal epidural labor analgesia in a morbidly obese parturient. J Clin Anesth 16: 461-464

66. ALBRIGHT G A, FORSTER R M 1999 The safety and efficacy of combined spinal and epidural analgesia/anesthesia ( 6.002 blocks) in a community hospital. Reg Anesth Pain Med 24: 117-125

67. COLEMAN L, CARVALHO B, LIPMAN S, SCHMIESING C, RILEY E Accidental intrathecal sufentanil overdose during combined spinal-epidural analgesia for labor.

68. CURRIER D S, LEVIN K R, CAMPBELL 1997 Dysphagia with intrathecal fentanyl. Anesthesiology 87: 1570-1571

69. FRAGNETO R Y, FISHER A 2000 Mental status change and aphasia after labour analgesia with intrathecal sufentanil/bupivacaine. Anesth Analg 90: 1175-1176

70. HAMILTON C L, COHEN S E 1995 High sensory block after intrathecal sufentanil for labour analgesia. Anesthesiology 83: 1118-1121

71. KUCZKOWSKI K M, GOLDSWORTHY M Transient aphonia and aphagia in a parturient after induction of comnined spinal epidural labor analgesia with subarachnoid fentanyl and bupivacaine.

72 SCAVONE B M 2002 Altered level of consciousness after combined spinal epidural labour analgesia with intrathecal fentanyl and bupivacaine. Anesthesiology 96: 1021-1022

73. CRITES J, RAMANATHAN J 2000 Acute hypoglycemia following combined spinal epidural anesthesia (CSE) in a parturient with diabetes mellitus. Anesthesiology 93: 591

74. KUCZKOWSKI K M 2003 Acute hypoglycaemia in a heathly parturient following induction of a combined spinal-epidural analgesia for labour. Anaesthesia 58: 480-501

75. BROMAGE P R 1999 Problems with combined spinal and epidural anesthesia. Reg Anesth Pain 24: 191

76. BIRNBACH D J, OJEA L S 2002 Combined spinal epidural (CSE) for labor and delivery. Int Anesthesiolog Clin 40: 27-48

77. CAMANN W 2000 Problems with combined spinal and epidural anesthesia. Reg Anesth Pain 25: 105

78. ALDEBERT S, SLETH J C 1996 Meningite bacterienne après anesthesie rachidienne et peridurale combinee en obstetrique. $A n$ Fran d'Anesth Reanim 15: 687-688

79. BOUHEMAD B, DOUNAS M, MERCIER F J, BENHAMOU D 1998 Bacterial meningitis following combined spinal epidural analgesia for labour. Anaesthesia 53: 290-295

80. CASCIO M, HEATH G 1996 Meningitis following a combined spinal epidural technique in a labouring term parturient. Can J Anaesth 43: 399-402 
81. HARDING S A, COLLIS R E, MORGAN B M 1994 Meningitis after combined spinal extradural anaesthesia in obstetrics. Brit J Anaesth 73: 574-577

82. PICKERING ANESTHESIOLOGY 1999 NORRIS M C, GRIECO W M, BORKOWSKI M, LEIGHTON B L, ARKOOSH V A, HUFFNAGLE H J, HUFFNAGLE J 1994 Complications of labor analgesia: epidural versus combined spinal epidural techniques. Anesth Analg 79: 529-537

83. BERGA S, TRIERWEILER M W 1989 Bacterial meningitis following epidural anaesthesia for vaginal delivery: a case report. Obstet Gynecol 74: 437-439

84. DAVIS L, HARGREAVES C, ROBINSON P C 1993 Postpartum meningitis. Aaesthesia 48: 788-789

85. NGAN KEE W D, JONES M R, THOMAS P, WORTH R J 1992 Extradural abscess complicating extradural anaesthesia for caesarean section. Brit J Anaesth 69: 647-652.

86. READY L B, HELFER D 1989 Bacterial meningitis in parturients after epidural anesthesia. Anesthesiology 71: 988-990

87. CRAWFORD J S 1985 Some maternal complications of epidural analgesia for labour. Anaesthesia 40: 1219-1225

88. HELLMANN K 1965 Epidural anaesthesia in obstetrics: a second look at 26127 cases. Can Anaesth Soc J 12: 398-404

89. PAECH M J, GODKIN R, WEBSTER S 1998 Complications of obstetric epidural analgesia and anaesthesia: a prospective analysis of 10995 cases. Int J Obstet Anesth 7: 5-11

90. PALOT M, VISSEAUX H, BOTMANS C, PIRE J C 1994 Epidemiology of complications of obstetrical epidural analgesia. Cah d'Anesth 42: $229-233$

91. SCOTT D B, HIBBARD B M 1990 Serious non fatal complications associated with extradural block in obstetric practice. BrJ Anaesth 64: 537

92. REYNOLDS F 2001 Damage to the conus medullaris following spinal anaesthesia. Anaesthesia 56: 238-247

93. CARVALHO J C 2008 Ultrasound facilitated epidurals and spinals in obstetrics. Anesthesiology Clin 26: 145-158

94. WHITTY R, GOLDSZMIDT E, PARKES R K, CARVALHO I C A 2007. Determination of the ED95 for intrathecal plain bupivacaine combined with fentanyl in active labor. Int J Obstet Anesth 16: $341-345$

95. NAGEOTTE M P, LARSON D, RUMNEY P J, SIDHU M, HOLLENBACH K 1997 Epidural analgesia compared with combined spinal epidural analgesia during labor in nulliparous women. New Engl J Med 337: 1715-1719

96. VAN DE VELDE M, SCHEPERS R, BERENDS N, VANDERMEERSCH E, DE BUCK F 2008 Ten years of experience with accidental dural puncture and post-dural puncture headache in a tertiary obstetric anaesthesia department. Int J Obstet Anesth 17: 329335

97. SEGAL S, TSEN L C, DATTA S 1990 Intrathecal catheter insertion following unintentional dural puncture reduces the requirement for epidural blood patch. Anesthesiology 4: A69

98. RUTTER S V, SHIELDS F, BROADBENT C R, POPAT M, RUSSELL R 2001 Management of accidental dural puncture in labour with intrathecal catheters: an analysis of 10 years experience. Int J Obstet Anesth 10: 177-181

99. NORRIS M C, LEIGHTON B L 1990 Continuous spinal anesthesia after unintentional dural puncture in parturients. Reg anesth 15: 285

100. COHEN S, DAITCH J S, GOLDINER P L 1989 An alternative method for management of accidental dural puncture for labor and delivery. Anesthesiology 70: 164

101. AIDA S, TAGA K, YAMAKURA T et al. 1998 Headache after attempted epidural block: the role of intrathecal air. Aesthesiology 88: $76-81$

102. LEO S, LIM Y, SIA A T 2008 Analgesic efficacy using loss of resistance to air versus saline in combined spinal epidural technique for labour analgesia. Anaesth Intensive Care 36: 701-706

103. BUGGY D 1999 Ambulation during regional analgesia for labour should be discouraged. Proposer. Int J Obstet Anesth 8: 179-180

104. DAVIES J, FERNANDO R, MCLEOD A, VERMA S, FOUND P 2002 Postural stability following ambulatory regional analgesia for labor. Anesthesiology 97: 1576-1581

105. COHEN S E, YEH JY, RILEY E T, VOGEL T M 2000 Walking with labor epidural analgesia. The impact of bupivacaine concentration and a lidocaine-epinephrine test dose. Anesthesiology 92: 387-392
106. GURBET A, TURKER G, KOSE D O, UCKUNKAYA N 2005 Intrathecal epinephrine in combined spinal-epidural analgesia for labor: dose response relationshipfor epinephrine added to a local anesthetic-opioid combination. Int J Obstet Anesth 14: 121-125

107. TSEN L C, THUE B, DATTA S, SEGAL S 1999 Is combined spinal epidural analgesia associated with more rapid cervical dilation in nulliparous patients when compared with conventional epidural analgesia. Anesthesiology 91: 920-925

108. CLARKE V T, SMILEY R M, FINSTER M 1994 Uterine hyperactivity after intrathecal injection of fentanyl for analgesia during labor: a cause of fetal bradycardia? Anesthesiology 81: 1083

109. COHEN S E, CHERRY C M, HOLBROOK R H, EL-SAYED YY, GIBSON R N, JAFFE R A 1993 Intrathecal sufentanil for labor analgesia-sensory changes, side effects, and fetal heart rate changes. Anesth Analg 77: 1155-1160

110. HONET J E, ARKOOSH V A, NORRIS M C, HUFFNAGLE H J, SILVERMAN N S, LEIGHTON B L 1992 Comparison among intrathecal fentanyl, meperidine, and sufentanil for labor analgesia. Anesth Analg 75: 734-739

111. KUCZKOWSKI K M 2004 Severe persistent fetal bradycardia following subarachnoid administration of fentanyl and bupivacaine or induction of a combined spinal epidural analgesia for labor pain. $J$ Clin Anesth 16: 78-79

112. NIELSEN P E, ERICKSON J R, ABOULEISH E I, PERRIATT S, SHEPPARD C 1996 Fetal heart rate changes after intrathecal sufentanil or epidural bupivacaine for labor analgesia: incidence and clinical significance. Anesth Analg 83: 742-746

113. PALMER C M, MACIULLA J E, CORK R C, NOGAMI W M, GOSSLER K, ALVERS D 1999 The incidence of fetal heart rate changes after intrathecal fentanyl labor analgesia. Anesth Analg 88: $577-581$

114. VAN DE VELDE M, VERCAUTEREN M, VANDERMEERSCH E 2001 Fetal heart rate abnormalities following regional analgesia for labor pain: the effect of intrathecal opioids. Regional Anesthesia and Pain Medicine 26 (3): 257-262

115. MARDIROSSOF C, DUMONT L, BOULVAIN M, TRAMER M R 2002 Fetal bradycardia due to intrathecal opioids for labour analgesia: a systematic review. Br J Obstet Gynaecol 109: 274-281

116. VERCAUTEREN M, BETTENS K, VAN SPRINGEL G, SCHOLS G, VAN ZUNDERT J 1997 Intrathecal labor analgesia: can we use the same mixture as is used epidurally? Int J Obstet Anesth 6: 242-246

117. NICOLET J, MILLER A, KAUFMAN I, GUERTIN M C, DESCHAMPS A 2008 Maternal factors implicated in fetal bradycardia after combined spinal epidural for labour pain. Eur J Anaesthesiol 25: 721-725

118. GAISER R R, MCHUGH M, CHEEK T G, GUTSCHE B B 2005 Predicting prolonged fetal heart rate deceleration following intrathecal fentanyl/bupivacaine. Int J Obstet Anesth 14: 208-211

119. ABRAO K C, VIEIRA FRANCISCO R P, MIYADAHIRA S, CICARELLI D D, ZUGAIB M 2009 Elevation of basal uterine tone and fetal heart rate abnormalities after labor analgesia. Obstet Gynecol 113: 41-47

120. EBERLE R L, NORRIS M C, MALLOZI EBERLE A, NAULTY J S, ARKOOSH V A 1998 The effect of maternal position on fetal heart rate during epidural or intrathecal labor analgesia. Am J Obstet Gynecol 179: 150-155

121. KAHN L, HUBERT E 1998 Combined spinal epidural analgesia, fetal bradycardia and uterine hypertonus. Reg Anesth Pain Med 23: 111-112

122. ALBRIGHT G A, FORSTER R M 1997 Does combined spinal epidural analgesia with subarachnoid sufentanil increases the incidence of emergency Cesarean delivery? Reg Anesth 22: 400-405

123. GAMBLING D R, SHARMA S K, RAMIN S M, LUCAS M J, LEVENO K J, WILEY J, SIDAWI J E 1998 A randomized study of combined spinal epidural analgesia versus intravenous meperidine durng labor. Anesthesiology 89: 1336-1344

124. COLONNA-ROMANO P, LINGARAJU N, GODFREY S D 1992 Epidural test dose and intravascular injection in obstetrics: sensitivity, specificity, and lowest effective dose. Anesth Analg 75: 372-376

125. NORRIS M C, FERRENBACH D, DALMAN H, FOGEL S T, BORRENPOHL S, HOPPE W, RILEY A 1999 Does epinephrine improve the diagnostic accuracy of aspiration during labor epidural analgesia? Anesth Analg 88: 1073-1076

126. MARCUS M A, VERTOMMEN I D, VAN AKEN H, GOGARTEN W, BUERKLE H 1998 The effects of adding isoproterenol to $0.125 \%$ bupivacaine on the quality and duration of epidural analgesia in laboring parturients. Anesth Analg 86: 749-752 
127. BIRNBACH D J, CHESTNUT D H 1999 The epidural test dose in obstetric patients: has it outlived its usefulness? Anesth Analg 88: 971-972

128. VAN DE VELDE M, DREELINCK R, DUBOIS J, KUMAR A, DEPREST J, LEWI L, VANDERMEERSCH E 2007 Determination of the full dose-response relation of intrathecal bupivacaine, levobupivacaine, and ropivacaine, combined with sufentanil, for labor analgesia. Anesthesiology 106: 149-156

129. CARVALHO B, WANG P, COHEN S E 2006 A survey of labor patient-controlled epidural anesthesia practice in California hospitals. IJOA 15: 217-222

130. BURNSTEIN R, BUCKLAND R, PICKETT J A 1999 A survey of epidural analgesia for labour in the United Kingdom. Anaesthesia 54: 634-640

131. VAN HOUWE P, HEYTENS L, VERCCRUYSSE P 2006 A survey of obstetric anaesthesia practice in Flanders. Acta Anaesthesiol Belg 57: $29-37$

132. LAMONT R F, PINNEY D, RODGERS P, BRYANT T N 1989 Continuous versus intermittent epidural analgesia. Anaesthesia 44: 893-896

133. D'ATHIS F, MACHEBOEUF M, THOMAS H, ROBERT C, DESCH G, GALTIER M, MARES P, ELEDJAM J J 1988 Epidural analgesia with a bupivacaine-fentanyl mixture in obstetrics: comparison of repeated injections and continuous infusion. Can J Anaesth 35: $116-122$

134. SMEDSTAD K G, MORISON D H 1988 A comparative study of continuous and intermittent epidural analgesia for labour and delivery. Can J Anaesth 35: 234-241

135. PURDIE J, REID J, THORBURN J, ASBURY A J 1992 Continuous extradural analgesia: comparison of midwife top-ups, continuous infusions and patient controlled administration. Brit J Anaesth 68: 580-584

136. SALIM R, NACHUM Z, MOSCOVICI R, LAVEE M, SHALEV E 2005 Continuous compared with intermittent epidural infusion on progress of labor and patient satisfaction. Obstet Gynecol 106: 301-306

137. BOUTROS A, BLARY S, BRONCHARD R, BONNET F 1999 Comparison of intermittent epidural bolus, continuous epidural infusion and patient controlled-epidural analgesia during labor. IJOA 8: $236-241$

138. FETTES P D W, MOORE C S, WHITESIDE J B, MCLEOD G A, WILDSMITH J A W 2006 Intermittent vs continuous administration of epidural ropivacaine with fentanyl for analgesia during labour. Brit J Anaesth 97: 359-364

139. USHA KIRAN T S, THAKUR M B, BETHEL J A, BHAL P S, COLLIS R E 2003 Comparison of continuous infusion versus midwife administered top-ups of epidural bupivacaine for labour analgesia: effect on second stage of labour and mode of delivery. IJOA 12: 9-11

140. TAN S, REID J, THORBURN J 1994 Extradural analgesia in labour: complications of three techniques of administration. Brit $J$ Anaesth 73: 619-623

141. HALONEN P, SARVELA J, SAISTO T, SOIKKELI A, HALMESMAKI E, KORTILLA K 2004 Patient-controlled epidural technique improves analgesia for labor but increases cesarean delivery rate compared with the intermittent bolus technique. Acta Anaesthesiol Scandinavica 48: 732-737

142. VANDERMEULEN E P, VAN AKEN H, VERTOMMEN J D 1995 Labor pain relief using bupivacaine and sufentanil: patient controlled epidural analgesia versus intermittent injection. Eur I Obstet Gynecol Reprod Biol 59: S47-S54

143. PAECH M J, PAVY T J G, SIMS C, WESTMORE M D, STOREY J M, WHITE C 1995 Clinical experience with patient-controlled and staff-administered intermittent bolus epidural analgesia in labour. Anaesth Intens Care 23: 459-463

144. GAMBLING D R, MCMORLAND G H, YU P, LASZLO C 1990 Comparison of patient-controlled epidural analgesia and conventional intermittent top-up injections during labor. Anesth Analg 70: 256-261

145. GAMBLING D R, YU P, MCMORLAND G H, PALMER L 1988 A comparative study of patient controlled epidural analgesia (PCEA) and continuous infusion epidural analgesia (CIEA) during labour. Can J Anaesth 35: 249-254

146. LYZAK S Z, EISENACH J C, DOBSON II C E 1990 Patient-controlled epidural analgesia during labor : a comparison of three solutions with a continuous infusion control. Anesthesiology 72: 44-49

147. SIA A T, CHONG J L 1999 Epidural 0.2\% ropivacaine for labour analgesia: parturient-controlled or continuous infusion? Anaesth Intensive Care 27: 154-158
148. CURRY P D, PACSOO C, HEAP D G 1994 Patient-controlled epidural analgesia in obstetric anaesthetic practice. Pain 57: 125-128

149. VISCOMI C, EISENACH J C 1991 Patient-controlled epidural analgesia during labor. Obstet Gynecol 77: 348-351

150. LEDIN ERIKSSON S, GENTELE C, OLOFSSON C H 2003 PCEA compared to continuous epidural infusion in an ultra-low-dose regimen for labor pain relief: a randomised study. Acta Anaesthesiol Scand 47: 1085-1090

151. COLLIS R E, PLAAT F S, MORGAN B M 1999 Comparison of midwife top-ups, continuous infusion and patient-controlled epidural analgesia for maintaining mobility after a low-dose combined spinal-epidural. Br J Anaesth 82: 233-236

152. FERRANTE F M, LU L, JAMISON S B, DATTA S 1991 Patient-controlled epidural analgesia : demand dosing. Anesth Analg 73: $547-552$

153. FERRANTE F M, ROSINIA F A, GORDON C, DATTA S 1994 The role of continuous background infusions in patient-controlled epidural analgesia for labor and delivery. Anesth Analg 79: 80-84

154. GAMBLING D R, HUBER C J, BERKOWITZ J 1993 Patient-controlled epidural analgesia in labour: varying bolus dose and lockout interval. Can J Anaesth 40: 211-217

155. SMEDVIG J P, SOREIDE E, GJESSING L 2001 Ropivacaine 1 $\mathrm{mg} / \mathrm{ml}$, plus fentanyl $2 \mathrm{microg} / \mathrm{ml}$ for epidural analgesia during labour. Is mode of administration important? Acta Anaesthesiol Scand 45: 595-599

156. VAN DER VYVER M, HALPERN S, JOSEPH G 2002 Patientcontrolled epidural analgesia versus continuous infusion for labour analgesia: a meta-analysis. Br J Anaesth 89: 459-465

157. VALLEJO M C, RAMESH V, PHELPS A L, SAH N 2007 Epidural labor analgesia: continuous versus patient-controlled epidural analgesia with background infusion versus without a background infusion. J Pain 8: 970-975

158. LIM Y, OCAMPO C E, SUPANDJI M, TEOH W H L, SIA A T 2008 A randomized controlled trial of three patient-controlled epidural analgesia regimens for labor. Anesth Analg 107: 1968-1972

159. MISSANT C, TEUNKENS A, VANDERMEERSCH E, VAN DE VELDE M 2005 Patient-controlled epidural analgesia following combined spinal-epidural analgesia in labour: the effects of adding a continuous epidural infusion. Anaesth Intensive Care 33: 452-456

160. OKUTOMI T, SAITO M, MOCHIZUKI J, AMANO K, HOKA S 2009 A double-blind randomized controlled trial of patient-controlled epidural analgesia with or without a background infusion following initial spinal analgesia for labor pain. IJOA 18: 28-32

161. WONG C A, RATLIFF J T, SULLIVAN J T, SCAVONE B M, TOLEDO P, MCCARTHY R J 2006 A randomized comparison of programmed intermittent epidural bolus with continuous epidural infusion for labor analgesia. Anesth Analg 102: 904-909.

162. SIA A T, LIM Y, OCAMPO C A COMPARISON OF A BASAL INFUSION WITH 2007 automated mandatory boluses in parturient-controlled epidural analgesia during labor. Anesth Analg 104: 673-678

163. LIM Y, SIA A T, OCAMPO C E 2006 Comparison of computer integrated patient controlled epidural analgesia vs. conventional patient controlled epidural analgesia for pain relief in labour. Anaesthesia 61: 339-344

164. ALBRIGHT G A 1979 Cardiac arrest following regional anesthesia with etidocaine or bupivacaine. Anesthesiology 51: 285-287

165. GROBAN L, DOLINSKI S Y 2001 Differences in cardiac toxicity among ropivacaine, levobupivacaine, bupivacaine, and lidocaine. Techn Reg Anesth Pain Management 5: 48-55

166. STIENSTRA R 2001 Ropivacaine for obstetric use. Techn Reg Anesth Pain Management 5: 60-63

167. MATHER L E, CHANG D H T 2001 Cardiotoxicity with modern local anaesthetics. Is there a safer choice? Drugs 61: 333-342

168. SANTOS A C, ARTHUR G R, WLOD Y D, DE ARMAS P, MORISHIMA H O, FINSTER M 1995 Comparative systemic toxicity of ropivacaine and bupivacaine in nonpregnant and pregnant ewes. Anesthesiology 82: 734-740

169. WRITER W D R, STIENSTRA R, EDDLESTON J M, GATT S P, GRIFFIN R, GUTSCHE B B, JOYCE T H, HEDLUND C, HEEROMA K, SELANDER D 1998 Neonatal outcome and mode of delivery after epidural analgesia for labour with ropivacaine and bupivacaine : a prospective meta-analysis. Brit J Anaesth 81: 713-717

170. ASIK I, GOKTUG A, GULAY I, ALKIS N, UYSALEL A 2002 Comparison of bupivacaine $0.2 \%$ and ropivacaine $0.2 \%$ combined 
with fentanyl for epidural analgesia during labour. EurJ Anaesthesiol 19: $263-270$

171. Comparative Obstetric Mobile Epidural Trial (COMET) Study Group UK 2001 Effect of low dose mobile versus traditional epidural techniques on mode of delivery: a randomised controlled trial. Lancet 358: 19-23

172. HALPERN S H, WALSH V 2003 Epidural ropivacaine versus bupivacaine for labor: a meta-analysis. Anesth Analg 96: 1473-1479

173. CAMPBELL D C, ZWACK R M, CRONE L A, YIP R W 2002 Ambulatory labor epidural analgesia: bupivacaine versus ropivacaine. Anesth Analg 90: 1384-1389

174. MEISTER G C, D'ANGELO R, OWEN M, NELSON K E, GAVER R 2000 A comparison of epidural analgesia with $0.125 \%$ ropivacaine with fentanyl versus $0.125 \%$ bupivacaine with fentanyl during labor. Anesth Analg 90: 632-637

175. GAUTIER P, DE KOCK M, VAN STEENBERGE A, MICLOT D, FANARD L, HODY J L 1999 A double blind comparison of $0.125 \%$ ropivacaine with sufentanil and $0.125 \%$ bupivacaine with sufentanil for epidural labor analgesia. Anesthesiology 90: 772-778

176. LEE B B, NGAN K E E WD, NG F F, LAU T K, WONG E L Y 2004 Epidural infusions of ropivacaine and bupivacaine for labor analgesia: a randomized, double blind study of obstetric outcome. Anesth Analg 98: 1145-1152

177. ATIENZAR M C, PALANCA J M, TORRES F, BORRAS R, GIL S, ESTEVE I 2008 A randomized comparison of levobupivacaine, bupivacaine and ropivacaine with fentanyl, for labor analgesia. Int J Obstet Anesth 17: 106-111

178. OWEN M D, THOMAS J A, SMITH T, HARRIS L C, D'ANGELO R 2002 ROPIVACAINE $0.075 \%$ and bupivacaine $0.075 \%$ with fentanyl $2 \mathrm{ig} / \mathrm{ml}$ are equivalent for labor epidural analgesia. Anesth Analg 94: 179-183

179. GOGARTEN W, VAN DE VELDE M, SOETENS F, VAN AKEN H, BRODNER G, GRAMKE H F, SOETENS M, MARCUS M A E 2004 A multicentre trial comparing different concentrations of ropivacaine plus sufentanil with bupivacaine plus sufentanil for patient controlled epidural analgesia in labour. Eur J Anaesthesiol 21: $38-45$

180. CHUA N P, SIA A T, OCAMPO C E 2001 Parturient controlled epidural analgesia during labour: bupivacaine vs ropivacaine. Anaesthesia 56: 1169-1173

181. FISCHER C, BLANIE P, JAOUEN E, VAYSSIERE C, KALOUL I, COLTAT J C 2000 Ropivacaine $0.1 \%$ plus sufentanil $0.5 \mu \mathrm{g} / \mathrm{ml}$ versus bupivacaine $0.1 \%$ plus sufentanil $0.5 \mu \mathrm{g} / \mathrm{ml}$ using patient controlled epidural analgesia for labor. Anesthesiology 92: 1588-1593

182. LACASSIE H J, COLUMB M O, LACASSIE H P, LANTADILLA R A 2002 The relative motor blocking potencies of epidural bupivacaine and ropivacaine in labor. Anesth Analg 95: 204-208

183. LEVIN A, DATTA S, CAMANN W R 1998 Intrathecal ropivacaine for labor analgesia: a comparison with bupivacaine. Anesth Analg 87: 624-627

184. HUGHES D, HILL D, FEE J P H 2001 Intrathecal ropivacaine or bupivacaine with fentanyl for labour. Brit J Anaesth 87: 733-737

185. LIM Y, OCAMPO C E, SIA A T 2004 A comparison of duration of analgesia of intrathecal $2.5 \mathrm{mg}$ of bupivacaine, ropivacaine, and levobupivacaine in combined spinal epidural analgesia for patients in labor. Anesth Analg 98: 235-239

186. CAMORCIA M, CAPOGNA G, COLUMB M O 2005 Minimum local analgesic doses of ropivacaine, levobupivacaine, and bupivacaine for intrathecal labor analgesia. Anesthesiology 102: 646-650

187. LACASSIE H J, COLUMB M O 2003 The relative motor blocking potencies of bupivacaine and levobupivacaine in labor. Anesth Analg 97: 1509-1513

188. VERCAUTEREN M P, HANS G, DE DECKER K, ADRIAENSEN H A 2001 Levobupivacaine combined with sufentanil and epinephrine for intrathecal labor analgesia: a comparison with racemic bupivacaine. Anesth Analg 93: 996-1000

189. CAPOGNA G, CELLENO D, FUSCO P, LYONS G, COLUMB M 1999 Relative potencies of bupivacaine and ropivacaine for analgesia in labour. Brit J Anaesth 82: 371-373

190. POLLEY L S, COLUMB M O, NAUGHTON N N, WAGNER D S, VAN DE VEN C J M 1999 Relative analgesic potencies of ropivacaine and bupivacaine for epidural analgesia in labour. Anesthesiology 90: 944-950

191. POLLEY L S, COLUMB M O, NAUGHTON N N, WAGNER D S, VAN DE VEN C J M, GORALSKI K H 2003 Relative analgesic potencies of levobupivacaine and ropivacaine for epidural analgesia in labor. Anesthesiology 99 (6): 1354-8
192. DUGGAN J, BOWLER G M R, MCCLURE J H, WILDSMITH J A W 1988 Extradural block with bupivacaine: influence of dose, volume, concentration and patient characteristics. Brit J Anaesth 61: 324-331

193. VAN DE VELDE M, DREELINCK R, DUBOIS J, KUMAR A, DEPREST J, LEWI L, VANDERMEERSCH E 2007 Determination of the full dose response relationship of intrathecal bupivacaine, levobupivacaine and ropivacaine, combined with sufentanil, for labor analgesia. Anesthesiology 106: 149-15

194. CAPOGNA G, CAMORCIA M, COLUMB M O 2003 Minimum analgesic dose of fentanyl and sufentanil for epidural analgesia in the first stage of labor. Anesth Analg 96: 1178-1182

195. POLLEY L S, COLUMB M O, WAGNER D S, NAUGHTON N N 1998 Dose-dependent reduction of the minimum local analgesic concentration of bupivacaine by sufentanil for epidural analgesia in labor. Anesthesiology 8: 626-632

196. VERTOMMEN J D, VANDERMEULEN E, VAN AKEN H, VAES L, SOETENS M, VAN STEENBERGE A, MOURISSE P, WILLAERT J, NOORDUIN H, DEVLIEGER H, VAN ASSCHE A F 1991 The effects of the addition of sufentanil to $0.125 \%$ bupivacaine on the quality of analgesia during labor and on the incidence of instrumental deliveries. Anesthesiology 74: 809-814

197. PALMER C M, CORK R C, HAYS R, VAN MAREN G, ALVES D 1998 The dose response relation of intrathecal fentanyl for labor analgesia. Anesthesiology 88: 355-361

198. HERMAN N L, CALICOTT R, VAN DECAR T K, CONLIN G, TILTON J 1997 Determination of the dose response relationship for intrathecal sufentanil in labouring patients. Anesth Analg 84: 12561261

199. STOCKS G M, HALLWORTH S P, FERNANDO R, ENGLAND A J, COLUMB M O, LYONS G 2001 Minimum local analgesic dose of intrathecal bupivacaine in labor and the effect of intrathecal fentanyl. Anesthesiology 94: 593-598

200. GORDHT, POST C, OLSSONY 1986 Evaluation of the toxicity of subarachnoid clonidine, guanfacine, and a substance P-antagonist on rat spinal cord and nerve roots. Anesth Analg 65: 1303-1311

201. EISENACH J C, GRICE S C 1988 Epidural clonidine does not decrease blood pressure or spinal cord blood flow in awake sheep. Anesthesiology 68: 335-340

202. AVELINE C, EL METAOUA S, MASMOUDI A, BOELLE P Y, BONNET F 2002 The effect of clonidine on the minimum local analgesic concentration of epidural ropivacaine during labor. Anesth Analg 95: 735-740

203. CHASSARD D, MATHON L, DAILLER F, GOLFIER F, TOURNADRE J P, BOULETREAU P 1996 Extradural clonidine combined with sufentanil and $0.0625 \%$ bupivacaine for analgesia in labour. Brit J Anaesth 77: 458-462

204. BRICHANT J F, BONHOMME V, MIKULSKI M, LAMY M, HANS P 1994 Admixture of clonidine to epidural bupivacaine for analgesia during labor: effect of varying clonidine doses. Anesthesiology 81: A1136

205. LANDAU R, SCHIFFER E, MORALES M, SAVOLDELLI G, KERN C 2002 The dose sparing effect of clonidine added to ropivacaine for labor epidural analgesia. Anesth Analg 95: 728-734

206. CHIARI A, LORBER C, EISENACH JC, WILDLING E, KRENN C, ZAVRSKY A, KAINZ C, GERMANN P, KLIMSCHA W 1999 Analgesic and hemodynamic effects of intrathecal clonidine as the sole analgesic agent during first stage labor. Anesthesiology 91: 388396

207. MERCIER F J, DOUNAS M, BOUAZIZ H, DES MESNARDSSMAJA V, FOIRET C, VESTERMANN M N, FISCHLER M, BENHAMOU D 1998 The effect of adding a minidose of clonidine to intrathecal sufentanil for labor analgesia. Anesthesiology 89: 594601

208. PAECH M J, BANKS S L, GURRIN L C, YEO S T, PAVY T I G 2002 A randomized, double blind trial of subarachnoid bupivacaine and fentanyl, with or without clonidine, for combined spinal/epidural analgesia during labor. Anesth Analg 95: 1396-1401

209. MISSANT C, TEUNKENS A, VANDERMEERSCH E, VAN DE VELDE M 2004 Intrathecal clonidine prolongs labour analgesia but worsens fetal outcome: a pilot study. Can J Anaesth 51: 696-701

210. POLLEY L S, COLUMB M O, NAUGHTON N N, WAGNER D S, VAN DE VEN C J M 2002 Effect of epidural epinephrine on the minimum local analgesic concentration of epidural bupivacaine in labor. Anesthesiology 96: 1123-1128

211. GAUTIER P E, DEBRY F, FANARD L, VAN STEENBERGE A, HODY J L 1997 Ambulatory combined spinal epidural analgesia for 
labor. Influence of epinephrine on bupivacaine-sufentanil combination. Reg Anesth 22: 143-149

212. COHEN S E, YEH J Y, RILEY E T, VOGEL T M 2000 Walking with labor epidural analgesia. The impact of bupivacaine concentration and a lidocaine-epinephrine test dose. Anesthesiology 92: 387-392

213. GOODMAN S R, KIM-LO S H, CILIBERTO C F, RIDLEY D M, SMILEY R M 2002 Epinephrine is not a useful addition to intrathecal fentanyl or fentanyl-bupivacaine for labor analgesia. Reg Anesth Pain Med 27: 374-379

214. OKUTOMI T, MOCHIZUKI J, AMANO K, HOKA S 2000 Effect of epidural epinephrine infusion with bupivacaine on labor pain and mother-fetus outcome in humans. Reg Anesth Pain Med 25: 228-234

215. OKUTOMI T, AMANO K, MORISHIMA H O 2000 Effect of standard diluted epinephrine infusion on epiudral anesthesia in labor. Reg Anesth Pain Med 25: 529-534

216. DOUNAS M, O'KELLY B O, JAMALI S, MERCIER F J, BENHAMOU D 1996 Maternal and fetal effects of adrenaline with bupivacaine for epidural analgesia during labour. Eur J Anaesth 13: 594-598

217. NGABUIB M, YAKSH T L 1994 Antinociceptive effects of spinal cholinesterase inhibition and isobolographic analysis of the interaction with $\mu$ and $\alpha 2$ receptor systems. Anesthesiology 80: 1338-1348

218. YAKSH T L, GRAFE M R, MALKMUS S, RATHBUN M L, EISENACH J C 1995 Studies on the safety of chronically administered intrathecal neostigmine methylsulfate in rats and dogs. Anesthesiology 82: 412-427
219. HOOD D D, EISENACH J C, TONG C, TOMMASI E, YAKSH T L 1995 Cardiorespiratory and spinal cord blood flow effects of intrathecal neostigmine methylsulfate, clonidine and their combination in sheep. Anesthesiology 82: 428-435

220. ROELANTS F 2006 The use of neuraxial adjuvant drugs (neostigmine, clonidine) in obstetrics. Curr Opinion in Anaesthesiol 19: 233-237

221. HABIB A S, GAN T J 2006 Use of neostigmine in the management of acute postoperative pain and labour pain. Drugs 20: 821-839

222. NELSON K E, D’ANGELO R, FOSS M L, MEISTER G C, HOOD D D, EISENACH J C 1999 Intrathecal neostigmine and sufentanil for early labor analgesia. Anesthesiology 91: 1293-1298

223. D'ANGELO R, DEAN L S, MEISTER G C, NELSON K E 2001 Neostigmine combined with bupivacaine, clonidine and sufentanil for spinal labor analgesia. Anesth Analg 93: 1560-1564

224. OWEN M D, OZSARAC O, SAHIN S, UCKUNKAYA N, KAPLAN N, MAGUNACI I 2000 Low dose clonidine and neostigmine prolong the duration of intrathecal bupivacaine-fentanyl for labor analgesia. Anesthesiology 92: 361-366

225. RANE K, SOLLEVI A, SEGERDAHL M 2003 A randomised double blind evaluation of adenosine as adjunct to sufentanil in spinal labour analgesia. Acta Anaesth Scand 47: 601-603

226. BUVANENDRAN A, MCCARTHY R J, KROIN J S, LEONG W, PERRY P, TUMAN K J 2002 Intrathecal magnesium prolongs fentanyl analgesia: a prospective, randomized controlled trial. Anesth Analg 95: 661-665 